\title{
What and How Do Psychotherapist Consider the Developmental Stages in Adult Psychotherapy?
}

\author{
Geon Ho Bahn \\ Department of Psychiatry, School of Medicine, Kyung Hee University, Seoul, Korea
}

정신치료자는 성인 정신치료 시 발달단계에 대하여 무엇을 그리고 어떻게 고려해야 하는가?

반 건 호

경희대학교 의학전문대학원 정신건강의학교실

There is less psychoanalytic research about adulthood compared with pre-adulthood periods. In orthodox psychoanalysis, there has been skepticism about the need or efficacy of psychoanalysis after age 40-50. Recently, new developmental tasks have been associated with young adults as well as older adults, and the need for psychotherapy to manage the conflicts of these developmental tasks has emerged. In young adulthood, individuation as an adult begins, including marriage, childbearing, and employment. Middle adulthood is a transition between young and late adulthood, and rather, the conflicts including midlife crisis are greater than before and after this period of transition. The main difference from the previous stages in middle adulthood is the acceptance of a diminishing life span and imminent death. Among the main factors impacting middle adulthood life are sex, and the presence of a spouse (partner), integral to sustaining intimacy. In elderly people nearing the end of life stage, the suicide rate is especially high compared to other age groups. The difference in sex ratio between men and women in late adulthood should be considered in understanding them. One of the hot topics of recent interest for the elderly is the lifestyles of centenarians. Their secret to good health is a key concern for researchers in gerontology. In summary, the development of mentality continues after adolescence until late adulthood, so mental health treatment is needed during and after young adulthood. Thus, customized psychotherapy techniques must be urgently developed to meet the needs of different age-groups and related development tasks.

Psychoanalysis 2019;30(4):79-88

KEY WORDS: Adulthood · Developmental milestones $\cdot$ Psychotherapy $\cdot$ Death $\cdot$ Separation-individuation.

Received: July 26, 2019 Revised: August 14, 2019 Accepted: August 16, 2019

Address for correspondence: Geon Ho Bahn, MD, PhD

Department of Psychiatry, School of Medicine, Kyung Hee University, 23 Kyungheedae-ro, Dongdaemun-gu, Seoul 02447, Korea

Tel: +82-2-858-8556, Fax: +82-2-957-1997, E-mail: mompeian@khu.ac.kr

\section{서 론}

평균 수명을 80년으로 가정할 때 성인기는 60여 년을 차 지한다. 생애 첫 1 년이 평생을 사는 데 필요한 성격이나 인 지기능을 결정하는 데 대단히 중요한 것은 틀림없으나, 기간 면에서만 따지면 성인기 60년은 유아기의 수십 배에 달하는 기간이다. 80 여 년을 살면서 사람은 시점에 따라 전혀 다른 입장과 위치에 놓이게 된다. 즉, 영유아기나 청소년기에는 자신의 부모와 조부모 세대가 있고, 초기 성인기에는 배우자

This is an Open Access article distributed under the terms of the Creative Commons Attribution Non-Commercial License (https://creativecommons.org/licenses/by-nc/4.0) which permits unrestricted non-commercial use, distribution, and reproduction in any medium, provided the original work is properly cited.
의 가족이 생기게 되므로 더 많은 윗세대를 만난다. 중년기 에 자기 자녀와 손주가 생기면 자기보다 아래 세대와 윗세 대가 생긴다. 초고령자가 되면 아래로만 3세대를 거느릴 수 도 있다. 새로운 입장과 위치에 따라 자신의 처세와 대처가 달라져야 한다. 이렇듯 연령대에 따라 변화에 적응하는 노력 과 준비가 성인기 발달 과제의 핵심이다.

Freud(1905)는 50세 이후에는 정신 과정(mental process) 의 탄력성이 거의 없고, 성 에너지나 활동 감소로 이와 관련 된 갈등도 줄어들기 때문에 이들 집단에게는 정신분석치료 가 의미가 없다고 하였다. 일부 소수 분석가들이 40세 이후 50 세까지도 정신분석 치료가 유의할 수 있다고 주장하였으 나 받아들여지지 않았다(Abraham 1927). 최근 Settlage 등 여러 분석가들이 프로이트의 중년기 이후 정신분석 무용론 
에 대해 반박 이론과 근거를 제시하고 있다(Schachter 등 2014). 특히 노년층 집단은 외로움과 상실에 대한 문제가 심 각하고, 이로 인한 노인 자살이 늘어나는 점도 강조하였다. 이들 집단에 대한 정신치료 필요성과 효과도 제시하였다.

정신분석이 위대한 이유 중 하나는 인간의 정신을 분석 대상으로 삼았다는 점과, 인간의 발달을 체계적으로 설명한 것이다. 발달이란 한 개체와 내외부 환경 간 상호작용의 결 과로 나타나는 행태, 기능, 행동을 말하며(Spitz 1965), 이는 평생 진행된다(Erikson 1963). Sigmund Freud는 정신성적 발달 이론을 통해 구강기, 항문기, 오이디푸스기, 잠복기를 정의하고, 연령대별로 발달 개념과 과제를 제시하였다(Bahn 2013). Anna Freud와 Melanie Klein의 소아기 발달 이론은 Margaret Mahler, René Spitz, John Bowlby 등에 의해 발전 하였다(Bahn 2013). 유아기의 분리개별화 경험은 삶 전반에 영향을 줄 수 있고, 유아기 공생관계였던 어머니를 잃어버리 면서 어머니를 내재화하거나 그로부터 벗어나려는 노력은 평생 지속된다(Mahler 1972).

청소년기와 성인기 발달 이론은 소아기에 비해 부족하다. 청소년기는 생물학, 법학, 심리학 등 학문적 입장에 따라 시 기를 구분하는 방법도 다르다(Bahn 등 2015). 성인기 이전 기 간은 20여 년을 자세하게 나누어 분석적으로 설명하고 있는 데 비해, 성인기는 수십 년에 이르는 긴 세월이지만 어떻게 나눌지도 확실하지 않다. 정신분석계 생애주기 심리학(psychoanalytic life-cycle psychology)의 아버지라고 할 수 있 는 Erikson(1963)은 초기, 중기, 후기 등으로 나누고, 초기 성 인기 발달 과제로 친밀감 대 소외감, 중년기는 생산성 대 정 체, 노년기는 통합성 대 절망감을 제시하였다. 그러나 1900 년 미국 인구의 평균 수명이 47.3세에서 2010년 78.7세로 늘 어났고(Crimmins 2015), 앞으로도 계속 늘어날 것을 감안하 면 과거 이론이 현대 사회의 변화를 모두 수용할 수는 없다. 평균 수명 증가와 더불어 현대 사회를 반영할 수 있는 새로 운 성인기 발달 과제 연구가 필요한 이유 중 하나로 grant study를 들 수 있다(Vaillant 2012). 하버드대학교 졸업생을 대상으로 한 70년 추적연구에서 중년기까지는 따뜻한 아동 기를 경험한 사람이 좀 더 성숙한 방어기제를 사용하였으나, 노년기에 접어들면 덜 따뜻한 아동기를 경험한 사람에서 성 숙한 방어기제 사용이 증가하였다(Martin-Joy 등 2017). 이 는 노년기에도 발달이 진행되고 있음을 시사한다. 생물학적 으로도 성인은 완성체라는 과거 이론은 잘못된 것임을 확인 하였고, 신경세포 사멸과 재생을 통해 성인기 중추신경계는 끊임없이 변화한다. Kandel(2008)은 인간의 기억, 자유의지, 결정인자(determinants), 정신분석 효과 입증에 대해 신경과 학적 접근이 필요함을 주장하였다. Sigmund Freud 역시 자
신의 무의식 연구를 증명할 만큼 생물과학이 발전하지 못하 였다고 기술한 바 있으므로, 정신분석을 생물학적으로 증명 하는 것은 결코 Freud의 의지에 반하는 것이 아니라는 점도 강조하였다. Peter Fonagy 등은 정신화 기능과 관련 있는 뇌구 조를 밝히는 연구를 통해 정신화와 가장 밀접한 부위는 medial prefrontal cortex, anterior cingulate라고 보고하였고, 정신화 는 물론 정신분석적 치료 효과를 신경 영상 연구를 통해 확 인하였다(Allen 등 2008).

우리나라 통계청에서는 65세 이상을 '노인'으로 분류하며, 2017년 전체 인구의 $13.8 \%$ 를 차지하였고 점차 증가하여 2045 년에는 47.7\%까지 늘어날 것으로 예상한다(Bahn 2018). 노 인 인구 중 건강하게 100 세 이상 살고 있는 경우 'centenarians'로 칭한다. 이들 집단이 죽음보다 두려워하는 것은 인지 기능 저하와 치매이다. 학자들이 이들에게 관심을 갖는 이유 중 하나는 이들의 건강 관리 비법이다. 이들의 공통점은 '적 극적인 삶과 '다양한 인간관계 추구'이다(Diamond와 Christian 2011). Centenarian 중에는 자신들의 정신건강 문제를 다뤄주기를 원하는 경우도 있으며, 고인이 된 Leo Rangell (1913 2011)처럼 97세까지 정신분석가로 활동한 경우나 102세까지 환자를 만났던 Hedda Bolgar(1909 2013)처럼 분 석가가 centenarian인 경우도 있다(Bahn 2018). 노인 정신치 료의 가치를 수용하려는 움직임이 늘고 있는 것은 사실이지 만 실제 근거를 찾기는 쉽지 않다. 예를 들어 Psychoanalytic Electronic Publishing에 수록된 자료를 보면 청소년기 관련 자료 248 편, 아동기 1,244 편인 데 비해, 노년기 관련 자료는 24편뿐이다(Schachter 등 2014). 또한 미국정신분석학회에 서 제공하는 프로그램은 주로 아동청소년과 초기 성인에 대 한 것이며 노인 치료 관련 프로그램은 극히 제한적이다.

따라서 본 강의에서는 성인 정신치료에서 고려해야 할 특 징적 현상과 관련 주제 이해를 위한 기초 작업으로 성인기 발달 단계와 발달 과제에 대하여 검토하였다. 성인기 발달단 계와 발달 과제에 대한 기본 틀은 Colarusso(1992)의 저서를 주축으로 이루어졌다.

\section{성인기 발달 이론}

\section{정신분석적 성인 발달 심리학}

인간 정신 발달연구의 시조격인 Sigmund Freud는 구강 기, 항문기, 오이디푸스기, 잠복기, 청소년기까지 연구하였 으며, 성인기까지 연구를 연장하지 않았다(Colarusso 1992). 이후 수십 년간 이 이론에 반론을 제기하는 것은 쉽지 않았 고, 평생발달이론의 원조격인 Erikson(1963)에 이르러 청소 년기 발달이론을 정립하는 과정에서 발달은 성인기까지 지 
속된다고 주장하였다. Erikson은 인간의 발달을 여덟 단계 로 분류하였고, 그중 성인기는 초기, 중기, 후기, 세 단계로 분류하였다. 각 단계별로 역동적 양극성을 제시하였으며, 정 신 발달에 미치는 사회문화적 영향을 강조하였고, 발달 진행 을 위한 갈등은 정상 과정이라고 주장하였다(Table 1). 이후 여러 학자들이 성인기 발달연구를 소개하였다. Levinson 등 (1978)은 인생 주기를 20년 단위로 나누어 성인기 이전 단계 (0 20세), 청년기(20 40세), 중년기(40 60세), 노년기(60 80세), 고령기(80세 이후)로 분류하였다(Table 1). 평생에 걸 쳐 인간은 진화하는 인생구조를 만들고, 이는 삶의 기본 무늬 이자 세상 속에서 살아가는 자기 유형이 된다. 이러한 인생구 조가 해당 시기의 발달 요구를 만족시키지 못하면 내적으로 수정과 변화의 시기를 거친다. Vaillant와 Vaillant(1990)는 독특한 연구를 진행하였다. 발달 과정의 종단연구인 grant study이다. 이 연구에서는 1939년 하버드대학교 재학 중이던 268명의 남학생을 대상으로 수십 년간 주기적으로 인터뷰와 설문 조사를 시행하여, 성인기에서 정신구조의 정상적 진화 를 증명함으로써 청소년기가 끝나면 정신구조가 고정된다는 기존 이론이 오류임을 확인하였다. Greenson(1992)은 자신의 삶과 경험을 토대로 성인기의 다섯 단계 이론을 제시하였다 (Table 1), 결혼하기, 부모되기, 살아온 길 돌아보기, 실수 없 이 나이 먹기(수용 또는 부정), 노년기(활기 또는 동면)로 나 누었다. "일관성 있고 즐겁게 권위를 잃지 않고 성인기를 지 내려면 용기, 정직함, 겸손함이 필요하다. 보람찬 삶이 되게 하려면 즐거운 일을 만들고 지속해야 한다. 성인기에 즐길 수 있는 삶을 사는 동물은 인간뿐이다. 실제 나이가 어떻든 재미 를 느끼면서 살아야 인생을 젊게 살 수 있다. 잘 웃고, 유머 감각을 유지하고, 무엇보다도 스스로 즐거워할 수 있는 능력 이야말로 성인기 삶의 위기를 최소화하거나 적어도 위기 속에 서도 살아남는 데 필수적이다." Greenson이 말한 내용은 최근 백 세 이상 건강하게 사는 사람들의 비결인 즐겁게 살기, 적극 적으로 살기와 일치한다(Bahn 2018). Colarusso와 Nemiroff (1981)는 정상 성인기 경험에 대한 설명과 이해, 그리고 이 러한 개념들을 성인 정신치료와 진단에 어떻게 적용할 것인 가에 대한 연구 결과를 발표하였다.

성인기 발달 연구는 흔히 두 가지 논란에 부딪힌다(Colarusso 1992). 첫째, 결정인자들의 중요성 여부에 대한 의문, 둘째, 노화와 발달의 양립 가능성이다. 프로이트가 비록 청 소년기 이후 성인기 발달을 언급하지는 않았으나 초기 논문 에서 발달 연속성에 대하여 다룬 바 있다. "정신분석학에서 사고(생각)로 발생하는 요인들에 대해서는 크게 생각하면 서, 타고난 기질적 요인에 대해서는 거의 언급하지 않았다. (중략) 우리는 이 두 가지 원인요소들을 반대되는 것으로 보

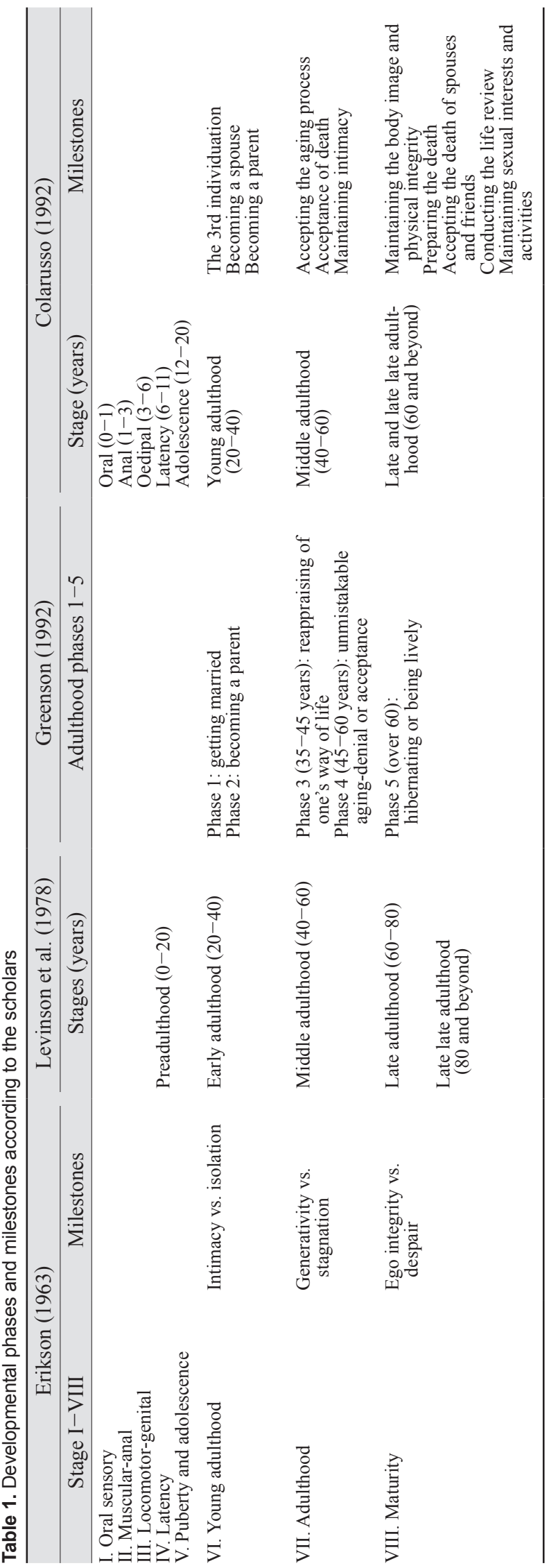


지 않는다. 오히려 두 가지 요소가 서로 정기적으로 협동 작 업을 하여 눈에 보이는 결과를 초래한다. 타고난 자질과 기 회는 그 사람의 운명을 결정한다. 그중 어느 하나만이 작용 하는 경우는 드물거나 없다"(Freud 1912). 이후 신경생물학 발전에 힘입어 위 두 가지 요인에 대한 논란은 줄어들고 있으 며, Colarusso와 Nemiroff(1981)의 성인기 발달 특징에 대한 가설이 지지와 이의 제기를 거치면서 이러한 논란은 줄어들 고 있다.

가설 1 은 '성인과 아동에서 발달 과정의 특성은 기본적으 로 동일하다'는 것이다. 즉, 아동기와 마찬가지로 성인기에도 생물학, 정신 내부, 환경 영향에 의해 지속적으로 발달이 진 행된다. 성인은 환경과 분리된 완성체가 아니며, 아이와 비슷 하게 계속 영향을 받는 역동적 긴장 상태에 있다. 따라서 가 설 2는 '성인 발달은 역동적 과정'이라는 것이며, 이는 출생부 터 아동기, 성인기를 거쳐 죽음에 이르기까지 계속됨을 시사 한다. 가설 3은 '아동기 발달이 일차적으로 정신구조의 형성 에 초점을 두고 있는 반면, 성인기 발달은 기존 정신구조와 적용이 지속적으로 진화한다'는 것이다. 가설 4는 '아동기의 근본적 발달 주제는 성인기에도 중심 주제이나 변형된 형태 로 나타난다'는 것이다. 예를 들어 Mahler(1972)의 영유아기 분리개별화는 청소년기와 성인기에도 형태는 다르지만 반복 해서 출현한다. 가설 5 는 '성인기 발달 과정은 어린 시절뿐 아 니라 이전 성인기 과거에 의해서도 영향 받는다'는 것이다. 가설 6에서 '성인기 발달은 아동기와 같이 신체 변화에 의해 크게 영향 받는다.' 가설 7에서 '성인 발달의 핵심적이고 단계 특정적 주제는 시간의 제한성과 개인의 죽음을 불가항력성 으로 인식하고 받아들임으로써 생겨나는 정상 위기'라고 강 조하였다(Colarusso 1992). 이후 Colarusso(1992)는 성인기를 청년기, 중년기, 노년기, 고령기 순으로 정리하였고, 각 단계 별 과제를 제시하였다(Table 1).

\section{청년기(20 40세)}

성인기 발달의 첫 단계는 청소년기에서 청년기로의 이행 이다. 이 단계는 '성인 세계인 사회로 진출하기 위해 가족에 대한 의존성을 떨치고 유아적 대상과의 애착이 느슨하게 되 는 과정'이다(Blos 1967). 이행 단계는 17 22세 사이의 5년여 에 걸쳐 진행되며, 이 시기의 목표는 '자신의 지평선을 탐험 하고 확장하며, 모든 조건이 분명해질 때까지 확신에 찬 선 택이나 결정을 미루고 인생의 기초를 구축하고 뿌리내리고 안정감과 지속성을 갖는 것'이다(Levinson 등 1978).

청년기의 발달 과제는 첫째, 성인으로서의 자기와 타인에 대한 감각의 발달이며, Colarusso(1992)는 이를 삼차 개별화 로 명명하였다. 참고로 1 차 분리개별화는 출생 후부터 약 3
세까지 기간으로 자기-대상 항시성(self-object constancy) 형성으로 이후 평생 대상 관계의 기초가 된다(Mahler 1972). 2차 분리개별화는 추상적 인지능력과 자기의식의 발달이 특 징이다(Blos 1967). 사춘기를 겪으면서 성-심리적 융합을 완 성함으로써 성인기의 성숙하고 친밀한 관계 형성 능력이 발 달한다. 3차 분리개별화는 20 40대, 4차는 40 60대, 5차는 60 80대에 진행된다(Colarusso 2000). 3 차 분리개별화 시기 에 대개 결혼과 자녀의 탄생을 경험한다. 일차적 관계 이외 의 관계를 통해 자기와 타인을 구분하며, 유아적 대상관계에 서 벗어나 타인과의 성적, 감정적 친밀감이 있는 관계를 맺 는다. 기존 3 차 분리개별화는 부모 입장을 고려한 것이나, 자녀 입장에서는 오히려 2차 분리개별화가 될 수 있다. 즉, 부모와 청소년 자녀 입장을 모두 고려한 '동시적 분리개별화 (synchronized separation-individuation)' 개념을 고려해 볼 수 있다(Moon과 Bahn 2016). 4차 분리개별화 시기는 부모 의 죽음, 자녀의 성장, 노화와 질병 등 다양한 변화를 겪는 다. 직업 기능의 하락과 손자 탄생을 경험하며, 죽음을 통해 남은 시간의 제한을 수용한다. 5 차 분리개별화 시기는 다가 오는 죽음을 받아들이며, 주변과의 관계 속에서 연결을 긴밀 하게 유지하며, 베풀기를 통해 통합을 완성한다. 성인기 이 전 및 이후의 분리개별화 이론은 일생 동안 이루어지는 신 체와 정신의 변화에 의한 자아 수정을 통해 발생하는 자기대상 항시성이라는 공통점이 있다(Colarusso 2000). 한편 성 인기의 분리개별화는 이전 단계에 비해 일차적 관계가 아닌 타인과의 상호작용을 통해 형성되며, 신체 발달보다는 퇴행 에 의해 영향을 받는다는 차이가 있다.

두 번째 발달 과제는 친밀한 관계를 형성할 수 있는 능력 발달, 즉, 결혼을 통한 배우자 되기이다. Erikson(1963)의 청 년기 발달 과제는 친밀감 대 고립감이다. 친밀감을 형성할 수 있는 능력은 정신적으로나 정서적으로 최상의 상태에서는 고등학교 졸업 후 약 4년 경과 시점이라고 한다(Offer와 Offer 1975). 친밀감 형성 능력은 청소년기의 신체적, 성적, 심 리적 변화로 인해 가능해진다(Colarusso 1992). 청소년기에 어린 시절 부모와 함께했던 가까운 관계가 없어지면서 느끼 게 되는 깊은 고독감이 친밀감을 형성하고자 하는 동력이 된다. 청년은 자신의 성 경험이 충분해지면 정서적 유대감을 느끼고 싶은 소망이 생긴다. 동반자와 성적 친밀감을 느끼게 되면 점차 서로를 동일시하게 되고, 자기 안의 여성성 또는 남성성을 투사하고 받아들이면서 이를 사랑하게 된다. 동반 자와의 성관계, 임신, 출산 경험을 통해 생식기에 대한 유아 적 사고방식을 포기하고, 서로의 생식기는 성적 만족감, 친 밀감, 그리고 출산을 위해 동등하며 상호 의존적 기능을 하게 된다. Grant study에서도 정신건강의 가장 분명한 장기적 예 
측 변인으로 오랜 세월 지속되는 행복한 결혼생활을 꼽았다 (Vaillant 1977).

청년기의 세 번째 과제는 생물학적, 심리적으로 부모가 되 는 것이다(Colarusso 1992). 연인관계였던 남녀는 서로에게 엄마, 아빠가 되는 환상을 가지고 있었을 것이다(Kestenberg 1976). 결혼과 임신은 이러한 관계의 재구조화를 필요로 하 며, 각자 자신의 위치를 잠재적 어머니, 잠재적 아버지로 재 배치하게 된다. 성교와 수정 과정은 부모에 대한 오이디푸스 기의 감정을 떠올리게 하며, 과거에는 금지되었던 임신에 이 르는 행위를 허락하도록 성인으로서의 초자아 수정이 필요 하다. 아기를 낳아 기르면서 아빠 또는 엄마가 된다는 것은 자신의 부모로부터 분리를 촉진한다. 과거에는 어버이의 특 권이라고 간주되었던 배타적 역할을 하면서 자신이 부모와 동등하다는 느낌이 생긴다. 자녀 양육 방식에 대해 끊임없이 의식적으로나 무의식적으로 비교를 통해 자기와 부모 사이의 차이점을 인식하고 동시에 세대 간 유대감과 연속성이 강화된 다(Colarusso 1992). 자녀를 낳고 부모되기를 스스로 포기하는 사람들도 있다. 이유는 다양하겠으나 그중 하나는 결혼생활 에서 자녀 양육이 주는 스트레스를 감당하고 싶지 않거나 감 당할 수 없다는 판단 때문이다. 다른 하나는 우리가 살고 있 는 세상에 대한 절망을 나타내는 것이기도 하다(Greenson 1992).

이러한 부모되기(parenthood)를 Irwin Marcus는 네 단계 로 분류하였다(Parens 1975). 자녀 출산과 성장 과정에서 부 모도 각각 부성애 감정, 모성애 감정을 겪으며 정신 내적으 로 변화한다. 1974년 콜로라도 덴버에서 개최된 미국정신분 석학회 연례학회에서 분석가들은 당시 미국 젊은이들이 결 혼을 미루고 자녀 갖기를 미루고, 갖더라도 적게 낳자는 추 세에 대해 논의하였다. 발제자들은 부모가 되려는 동기 없이 성인으로 성숙해지는 것이 가능한지, 어릴 적 성격 발달 문제 가 결과적으로 이러한 동력 저하로 이어진 것인지, 결혼을 미루는 것이 부모되기와 별개인지 등을 논의하였다. 논의의 핵심은 부모되기를 발달 과정으로 볼지 적응 단계로 볼 것 인가이다. 즉, 성인되기(adulthood)와 부모되기를 정신성적 발달 이론에 어떻게 도입할까이다. 잠정적 결론은 정신성적 발달과 인격 발달을 구분하자는 것이다. 따라서 한 개인은 부모가 되지 않아도 성숙한 어른이 될 수 있다.

부모되기와 관련된 주제 중 하나는 경계성 아빠에 대한 내용이다. 왜냐하면 사춘기 발달 과제와 함께 정신병리도 성 인기로 이어질 수 있다. 특히 Lansky(1987)는 경계성 정신병 리가 초기 성인기 아빠되기에 미치는 기전을 보고하였다. 아 빠가 되기 위해서는 아빠 노릇을 해야 한다. 아기와 엄마에 게 정서적으로나 물질적으로나 지원을 해 줘야 하고, 아내와
남편 사이의 양자관계 독점을 아기 출현으로 인해 상실하는 상황을 감당해야 함을 의미한다. 경계성 인격장애 환자들의 부모의 결혼생활은 흔히 부부 사이에 공개적으로 분노를 퍼 붓는 전쟁터로 묘사된다. 아버지는 대개 폭력적이고, 부적절 하며, 종종 술에 취하고, 거의 항상 상대에게 모욕감을 주는 인물이다. 어머니는 대개 혼란스러워하며 통합기능이 떨어 져 보인다. 난폭한 아버지에게서 자녀를 보호하는 이는 어머 니이며, 그래서 어머니는 대개 희생자가 된다. 이는 훗날 경 계성 인격 성향의 자녀가 분리(splitting), 비조직화(disorganization) 같은 방어기제를 사용하게 되는 근거가 된다. 경계 성 남편은 아내와의 양자관계 유지를 원하지만 아기의 출현 은 아빠의 질투와 선망을 자극한다. 인격의 비조직화와 수치 심이 점차 커지면서 증상 행동으로 이어진다. 과도한 음주 또는 자해 및 자살시도 증가 등이다.

발달 이론에서 남녀 구분이 필요할 때가 있다. Settlage와 Galenson(1976)은 청소년기 후반부터 초기 성인기 사이의 여성 심리 변화에 대해 기술하였다. Freud 시절에는 당시 사 회문화적 분위기 때문에 여성의 재생산 기능, 즉, 임신과 출 산에 초점을 맞추었다. 이후 세월이 흐르면서 여성 입지에 대한 개념은 크게 바뀌었다. 초기 청소년기는 사춘기 변화에 맞서는 시기이며, 후기 청소년기는 욕동과 새로운 성인기 능 력을 실험하고 숙달하는 단계이며, 자기, 초자아, 자아이상 감각의 수정이 필요하다. 초기 성인기는 성인의 능력을 시험 하고 강화하는 시기이다. 여성 심리에 초점을 맞춘다면 특별 히 두 가지를 개정할 필요가 있다. 첫째, 여성 성(gender) 정 체성이란 임신과 엄마되기(motherhood)를 필수조건으로 하 기보다는 이들로 인해 강화된다고 볼 수 있다. 둘째, 새로운 발달 이론으로부터 알게 된 것은 생후 첫 2년째 정상적으로 겪는 남성 성기 선망 갈등이 오이디푸스 전기와 오이디푸스 기에 해소된다는 점이다. 하지만 남성 성기 선망과 같은 현상 이 여성에게 평생 과제로 지속되는 것은 아닌지, 혹은 생애 어느 시점에 해소되는지에 대한 논란은 여전히 남아 있다.

네 번째 과제는 부모로부터의 심리적 분리와 부모의 중년 기 발달 촉진이다(Colarusso 1992). 청년기에는 부모와의 관 계에서 현실적으로나 심리적으로나 모두 큰 변화, 즉, 3차 분리개별화 과정을 겪는다(Colarusso 1995). 3차 분리개별화 는 청년기와 중년기에 걸쳐 이루어진다. 이때 고려해야 할 사항은 청년기 자녀가 겪는 분리개별화와 중년기 부모가 겪 는 분리개별화는 동시에 한 가족 내에서 일어난다는 점이다. 따라서 분리개별화 현상은 일방적이 아니고 자녀와 부모 입 장을 함께 고려한 양방향성 '동시적 분리개별화(synchronized separation-individuation)'로 이해해야 한다(Moon과 Bahn 2016). 네 번째 발달 과제 과정은 서로 연결된 세 단계 
로 이어진다. 1단계는 지속적인 부모로부터의 심리적 분리 과정이다. 모든 청년기 성인의 무의식과 초자아/자아이상 속에는 아동기로부터 형성된 남편, 아내, 부모로서의 행동방 식들이 프로그램화되어 있다. 이러한 이상화된 부모에 대한 기대는 자신들이 처한 현실에 따라 수정된다. 배우자는 동일 시와 기본 욕구 충족 대상으로 내재화되고, 새로운 대상들이 심리적으로 중요한 역할을 하게 되면서 이전부터 내재되어 있던 부모의 영향력은 점차 감소한다. 2단계에서 청년기 성 인이 배우자를 내재화하고 나면, 부모와의 평등하고 상호 존 중하는 관계에 변화가 생긴다. 즉, 부모의 심리적 표상은 의 존하고픈 대상에서 상호적이며 평등한 대상으로 변한다. 3 단계에서 역할 전환이 일어날 수 있다. 부모와의 평등하고 상호적 관계가 청년기와 중년기 내내 지속될 수도 있지만, 이는 부모의 정신적, 신체적 건강에 달려 있다. 어느 시점에 선가 심리적, 신체적으로 허약해지고 의존적이 된 부모를 돌 봐야 하는 상황이 생길 수 있다. 정상 성인이라면 초자아의 새로운 요구에 따라 역전된 부모-자녀 관계 안에서 보호자 의 역할을 맡게 된다.

\section{중년기(40 60세)}

17세부터 45세까지의 청년기는 중년기 이행기(40 45세) 라고 불리는 기간에 도달하면 종료된다(Levinson 등 1978). 중년기로의 이행은 신체 노화, 자녀들이 청소년기와 청년기 에 돌입함, 직업 성취 또는 실패, 부모 노화, 질병, 죽음 같은 강력한 심리적, 생물학적 요인에 의해 진행된다(Colarusso 1992). 중년기의 주요 발달 과제는 첫째, 신체 노화 현상 받 아들이기이다(Colarusso 1992). 중년기의 각 개인은 신체 변 화를 정신적으로도 경험한다. 의식 및 무의식 수준에서 자기 애적으로 상처를 받고, 과거의 몸과 현재를 비교한다. 이렇 듯 고통스러운 과정을 거쳐 노화를 거부하려는 소망과 젊은 신체 상실을 수용하려는 정상적 갈등을 경험한다. 노화를 병 적으로 거부하려는 시도로는 성형술, 젊은이와의 부적절한 물리적 경합, 신체 대체물을 통한 자기애적 만족(고급 의류, 자동차 등), 건강검진 회피 등이 있다. 노화가 진행되는 것에 대한 실제 해결책은 없겠으나, 점차 현실적으로 신체 변화를 받아들이며, 적절히 가꾸고 돌봄으로써 중년의 신체를 즐길 수 있는 능력을 키워나간다.

두 번째 과제는 시간의 한계와 죽음 받아들이기다 $\left(\mathrm{Co}^{-}\right.$ larusso 1992). 생물학적 및 환경적 변화, 신체 노화, 부모나 친구의 죽음, 자녀들이 성인이 됨, 조부모 되기, 은퇴 시점이 다가옴 등이 자극이 된다. 남은 생에 시간 제한이 있음을 느 끼고, 자신도 죽을 것임을 인식하게 된다. 이러한 자극과 인 식은 삶에 대한 강력한 조정 요인이 된다. 살아온 삶에 대한
총체적 재점검, 결혼, 가정, 직업에 대한 현 상태 재평가, 남 은 시간 활용에 대한 계획 세우기 등이다.

세 번째 과제는 친밀함, 사랑, 성 유지하기이다(Colarusso 1992). 청년기는 친밀감을 위한 능력 개발에 주력하는 반면, 중년기는 신체적, 심리적, 환경적 압박이 늘어나면서 친밀감 유지에 주력한다. 중년기는 청년기보다 더 많은 환경 변화를 경험한다(Colarusso 2000), 즉, 자녀가 자라면 떠나 보내기도 하고, 자녀의 결혼이나 손주들 출생으로 자신이 조부모가 되 는 등 자녀들과 평등한 입장에 놓이게 되고, 새 가족 구성원 이 늘어난다. 자기 부모들과의 관계에도 많은 변화가 생긴 다. 자신이 부모의 보호자가 되는 역할 역전, 부모의 죽음을 통한 새로운 형태의 분리-개별화를 경험한다. 직장에서는 능 력 발휘 요구가 늘어나고, 지위에 따른 역할 변화가 필요하 다. 신체 변화에 따라 놀이도 달라질 수 있으며, 노화에 맞는 종목을 찾아낸다. 시간의 한계와 죽음을 수용하는 발달 과제 를 담은 놀이, 예를 들면 골프나 카드게임을 선호한다 $\left(\mathrm{Co}^{-}\right.$ larusso와 Nemiroff 1981). 이러한 게임은 시작과 끝이 하나 뿐인 삶과 달리, 시작과 끝이 있지만 새로운 시작을 반복할 수 있다. 성기능 저하는 정상 변화임에도 불구하고 개인에 따라 심리적 반응은 차이가 많다. 남성은 발기 유지가 어려 워지고 사정 후 불응기가 길어지며, 여성은 에스트로겐 감소 로 인해 성생활의 지장을 초래한다. 중년기에 일어날 수 있 는 이혼이나 재혼 같은 환경 변화도 적응에 어려움을 초래 할 수 있다.

다른 연령대에 비해 중년기에는 '과도기' 또는 '위기'라는 병적 상황이 나타날 수 있다. '중년기 위기(mid-life crisis)'라 는 용어는 Jaques(1965)가 처음 사용하였고, 당시에는 35세 전후에 여러 가지 변화 또는 빠른 전환기에 나타나는 현상 으로 소개하였다. 여성에서는 폐경과 맞물리면 구분하기가 어렵고, 남성에서도 이즈음 성 행동 강도가 감소하기 때문 에 남성 갱년기(climacteric)라고 불리기도 하였다. 중년을 의미하는 단어 '중간(middle)'은 말 그대로 젊은 세대와 노 인 세대에 낀 중간 세대를 말하며, 그들이 겪는 우울감과 불 안감을 '위기'로 여길 수 있다. 오늘날 중년 위기라는 용어는 Jacques가 지칭한 35세 전후보다는 훨씬 뒤에 발생하는 심 리적 변화를 의미한다. 문학 작품 속에서도 중년기 위기를 찾아볼 수 있다(Colarusso와 Nemiroff 1981). Somerset Maugham의 소설 '달과 육펜스(The moon and six pence)' 에 나오는 주인공 Charles Strickland는 성공한 영국 은행가 로, 가장이지만 어느 날 가족에게 말도 없이 가족과 직장을 버리고 화가가 되기 위해 폴리네시아로 떠난다. 이 소설의 모티브는 실존 화가인 Paul Gauguin이 아내와 자녀를 버리 고 타히티로 그림을 그리기 위해 떠난 실화를 소재로 하였 
다고 한다. '고갱증후군'은 중년기 위기를 대표하는 용어로 사용된다.

융 학파에서도 중년기 위기를 다루고 있다. 미국 텍사스주 휴스턴에서 활동하는 융 분석가인 Hollis(1993)는 중년에 경 험하게 되는 난제들을 '중간 항로(middle passage)' 또는 중 년기 위기라고 표현하였다. 탄생과 죽음은 끝이 아닌 과정일 뿐이고, 중간 항로를 통해 잠재력을 이끌어내고 노년기의 성 숙한 지혜와 활력을 터득해야 한다. 중간 항로는 가짜 자기로 부터 확실성으로 가는 단계를 상징한다. 융 학파 입장에서 인 생의 단계를 설명하는 방법 중 하나로 네 단계의 정체성 (identity) 변화를 소개하였다(Hollis 1993). 첫 번째 정체성은 아동기로 거의 모든 것을 부모에게 의존하는 시기이다(고대 에는 사춘기 시작이 곧 성인기의 시작이었다. 즉, 의존하는 아동기에서 성인기의 독립으로 넘어갔다). 두 번째 정체성 단계는 사춘기에 시작된다. 저자는 이 시기를 대략 열두 살 부터 사십 세까지로 보았으며, 1차 성인기(first adulthood) 로 명명하였다. 이 시기에 자아는 부모를 떠나 더 큰 세상으 로 나갈 만큼 강해져야 하며, 생존과 성취를 위해 투쟁할 수 있어야 한다. 그러나 어떤 이는 나이가 들어 몸은 성인이 되 어도 부모에게 의존해서 살며(Kronos-adult body), 정신기 능은 여전히 아동기에 머물기도 한다(Kairos-childhood). 세 번째 정체성 단계는 2 차 성인기이다. 이 시기의 과제는 잠정적 정체성을 버리고 거짓 자아를 묻어버리는 것이다. 이 러한 상실의 고통은 새로운 삶으로 보상받을 수 있다. 네 번 째 정체성은 죽음의 신비와 함께 살아가는 단계이다. 중년기 중간 항로 기간 동안 계속 발달할 수 있는 근거 중 하나를 융 의 자서전을 인용하여 다음과 같이 설명하였다. "나는 사람 들이 인생 관련 의문에 대한 잘못된 또는 부적절한 답을 가 지고 있을 때 신경증이 생기는 경우를 종종 보곤 한다. 사람 들은 직위, 결혼, 명성, 성공, 돈을 추구하면서도, 원하는 것 을 얻었을때조차 행복해지지 못하고 신경증이 생긴다. 그들 은 좁은 영적 세상에 갇혀 있다. 그들의 삶은 내용도 의미도 충분하지 않다. 인격이 더 성장할 수 있다면 신경증은 대개 사라진다"(Hollis 1993). Colarusso의 5 차 분리개별화가 진 행되면서 만나는 것도 역시 죽음이듯이, 중년기 위기를 극복 하고 나면 기다리는 것은 죽음이다. 즉음이란? 융 학파의 핵 심 질문이 답이 될 수 있다. "우리는 뭔가 무한한 존재인가 아닌가?"(Hollis 1993).

\section{노년기(60 80세)와 고령기(80세 이후)}

노년기와 고령기를 구분할 수는 있으나 따로 언급할 만큼 자료가 충분치 않으므로 '노년기’로 통칭하여 기술하고자 한 다. 노년기의 발달 과제는 첫째, 신체상(body image)과 신체
적 온전함 유지이다(Colarusso 1992). 신체상은 인생 전반에 걸쳐서 신체 변화 외 신체에 대한 요구와 기대의 변화를 반 영하는 몸에 대한 정신적 표상을 말하며, 이는 개인의 감정 상태에 영향을 미친다. 상당수에서 신체상은 실제 외모를 닮 았으며, 얼마나 잘 유지되고 기능하느냐에 따라 자기 만족을 느끼기도 하고 좌절하기도 한다. 심리적으로도 '나는 누구인 가'에 대한 정신적 인식의 중요한 부분으로 경험된다. 두 번 째 과제는 죽음 준비다(Colarusso 1992). 중년기는 남은 시 간의 한계와 죽음의 불가피함을 인식하지만, 노년기에는 죽 음을 준비하는 것으로 발달 과제가 바뀐다. 세 번째 과제는 배우자와 친구의 죽음 받아들이기이다(Colarusso 1992). 오 랜 기간 결혼생활을 함께했던 배우자의 사망은 특히 두 가 지 변화를 일으킨다. 하나는 배우자와의 관계에 기반한 동일 시가 약해지는 것이며, 다른 하나는 애도 과정이 지속적 동 일시 과정에 방해가 된다는 점이다. 그러나 건강한 사람이라 면 궁극적으로 사랑했던 배우자 대신 자녀들이나 친구들과 의 관계를 강화하여 새로운 내적 균형을 구축한다. 배우자 사망 후 결혼생활 동안 억압 또는 억제되어 있던 재능, 성향, 성적 욕구 등이 발휘되는 경우도 있다. Colarusso(2000)는 이 를 배우자 사후 개별화(postspousal individuation)라고 명명 하였다.

중년기에서 노년기로 이어지는 동안 아버지와 자녀 사이 의 역동은 서서히 변화하며, 자녀에 대한 나이 든 아버지의 태도는 몇 가지 요인에 따라 달라진다(Colarusso 2005). 우 선 자녀의 결혼 상태, 경제력, 손주들이 영향을 준다. 성인이 된 자녀가 잘 살고 있으면 아버지는 자신이 주변으로 밀려 나는 느낌을 잘 수용할 수 있으며, 심지어 죽음에 대해서도 관대해진다. 반대로, 자녀들이 어려움에 처해 있다면 고통스 럽고 더 열심히 뭔가를 해줘야 한다는 책임감을 느낀다. 성 인 자녀에 대한 태도에 영향을 주는 다른 요소로 이미 돌아 가신 자신의 아버지와의 성인기 경험을 들 수 있다. 노년기 아버지가 성인 자녀를 대하는 태도에 영향을 주는 또 다른 요소는 자신과 아내가 더 나이가 들고 돌봄이 필요할 때, 자 식들이 기꺼이 자기들에게 도움을 줄 것인가 하는 것이다.

노년기의 네 번째 발달 과제는 인생 되돌아보기이다 $\left(\mathrm{Co}^{-}\right.$ larusso 1992). 인생 되돌아보기에 주로 사용되는 정신기전 은 회상(reminiscence)이다. 회상을 통해 과거와 현재의 연 속성을 유지하고, 자신이 어떻게 살아왔는가에 대한 감각을 강화시킬 수 있다. 회상을 통해 결과적으로 통합감 또는 절 망감에 다다른다(Erikson 1963). 통합감을 느낀다면 자신의 인생에 대해 만족함을 느끼는 것이고, 절망감을 느낀다면 자 기 인생이 공허하다는 것이므로 죽음을 두려워하게 될 수도 있다. Alfred Adler 역시 인생의 마지막 시험대를 바로 늙는 
것과 죽음에 대한 두려움이라고 하였다(Hoffman 2019). 즉, 자식을 통해, 그리고 문명의 발전에 기여함으로써 자신이 영 원히 산다고 확신하는 사람은 이런 두려움으로 겁먹지 않을 것이다.

다섯째 발달 과제는 성적 관심과 활동 유지하기이다 $\left(\mathrm{Co}^{-}\right.$ larusso 1992). 노인 인구의 증가와 더불어 노인의 삶의 질에 대한 관심도 늘고 있는데, 삶의 질에 관여하는 주요 인자 중 하나는 성생활이다(Bahn 2018). 노년기 성생활은 노인의 우 울 수준을 낮추고 행복감을 유지하도록 돕는다(Yoon 2019). 노년기 성기능은 연령보다는 신체 및 정신 건강과 관련이 높다(Park과 Chung 2019). 청소년기나 초기 성인기에 비해 노인의 성 욕구는 줄어들지 않지만, 신체 상태나 만성 질병 등으로 인해 성생활이 위축될 수 있다. Lindau 등(2007)의 보 고에서는 57세부터 85세까지 성인 성생활의 빈도는 18 세부 터 59세까지의 빈도와 유사하였다. 국내 연구에서 60세 이상 남성의 $38.3 \%$ 가 성생활을 하고 있으며, 여성은 $12.4 \%$ 로 낮 았다(Jeong 등 2012). 남성에서 성생활을 하지 않는 이유는 발기부전, 성욕 감소가 많았고, 여성은 배우자가 없거나 배 우자의 발기부전 때문이 많았다. 성생활이라고 하면 성교만 을 생각하기 쉽지만 손잡기, 쓰다듬기, 포옹 등과 같이 육체 적 친밀감 표현 등도 성행위이다(Witherow 등 2017). 노년에 활발한 성생활을 하기 위해서는 첫째, 신체 건강 유지, 둘째, 배우자 혹은 성생활 동반자의 존재, 셋째, 젊었을 때부터 규 칙적인 성생활을 하는 것이 중요하다(Park과 Chung 2019).

발달 과제 외 노년기에 심각하게 고려해야 할 주제로 자 살을 들 수 있다. 노인은 다른 어떤 연령층보다 자살 성공률 이 높다. 노년기에는 전쟁이나 자연재해를 제외하면, 일상생 활에서 다양한 상실에 맞닥뜨린다(Schachter 등 2014). 친구 나 사랑하는 사람들 상실, 부모의 죽음, 근력, 시력, 청력, 기 억력 상실과 같은 건강 문제, 전문가로서의 정체성 상실, 사 회적 지위와 수입 상실, 자존감 상실 등은 우울증으로 이어지 고 자살 위험을 높인다. 미국에서 2007년 인구 100,000 명당 자살률은 11.3 명이고, 65 세 이상 자살자는 14.9 명이며, 백인 노인 남성은 29명으로 가장 높다(Schachter 등 2014). 한편 고령 여성 인구 자살률은 남성보다 훨씬 낮다. 그 이유로는 과부로 오래 살 것을 예상하고 오래전부터 심리적으로 대비 하기 때문일 수 있다(Colarusso 2000). 어릴 때부터 할머니, 엄마, 여성 친척 등을 통해 혼자 사는 여성을 관찰할 수 있고, 나이가 들어가며 주변에서 비슷한 경험과 관찰을 반복해 왔 기 때문이다. 두 번째 이유로는 남성에 비해 여성이 정서적 으로 타인과 교류하는 능력이 좋은 편이다. 즉, 남성에 비해 고령 여성은 배우자 사망이나 이혼 후 혼자 살기 등의 상실 에 좀 더 잘 적응하는 편이다. 사회적 관계망에 대한 흥미로
운 통계가 있다. 2017년 우리나라 국민 중 다음 경우 도움을 받을 수 있다고 응답한 비율에서 세 가지 모두 여성이 남성 보다 높았다(Statistics Korea 2018). '낙심하거나 우울해서 이 야기 상대가 필요한 경우, ‘몸이 아파 집안일을 부탁해야 하 는 경우', '갑자기 많은 돈을 빌려야 할 경우' 도움을 받을 수 있다고 한 비율은 여성 대 남성은 각각 $86.0 \%$ 대 $81.2 \%$, $78.8 \%$ 대 $77.9 \%, 52.0 \%$ 대 51.9\%였다. 2013년 이후 계속 여 성이 남성보다 높았다.

노년기 관련 주제 중 짚고 넘어가야 할 주제 가운데 하나 는 성비 불균형이다. 90 세 이상이 되면 남녀 사망률은 비슷 해지지만, 70 세 이상 여성 생존자 수는 남성에 비해 월등히 많다(Jacobs 등 2014). 우리나라 경우 2018년 기준으로 볼 때 여성 인구는 총 인구의 $49.9 \%$ 를 차지하지만, 60 세 이상은 여 성 인구가 많다(Statistics Korea 2018). 즉, 0 9세에서 남녀 성비는 105.5, 20 29세는 114.0으로 남성 인구가 많지만, 60 69세 95.1, 70 79세 79.0, 80세 이상은 47.3이다. 100세 이후에는 남녀 성비가 약 $1: 5$ 로 여성이 월등히 많다. 정신치 료자 입장에서도 고령 여성 환자를 진료할 확률이 남성 환자 보다 높을 것이며, 남녀 성에 따라 요구 사항이 다를 것이 예 상된다(Bahn 2018).

초고령 집단이 늘면서 고령기 인구 중 100 세를 넘어 건강 하게 살고 있는 경우를 'centenarian'이라고 한다. 100세 이 상인 사람의 가족들을 대상으로 '당신도 100 세 이상 살고 싶 은가?'라는 설문 조사 결과 $56.5 \%$ 가 '예’라고 답하였다 (Brandão 등 2019). 단, 독립적으로 기능할 수 있어야 하며, 건강해야 한다는 조건이 달렸다. '아니오'라고 답한 나머지 구성원들의 이유는 건강 때문에 가족에게 짐이 되기 싫어서 였다. 즉, 원하는 집단이나 거부한 집단 모두 질병에 대한 부 담이 공통점이다. 그런 점에서 고령자의 간병 문제는 본인이 나 가족 모두 걱정하는 매우 중요한 주제이다. Centenarian 에서 가장 중요한 발달 과제는 '오래 살기'가 아니고 '건강하 게 오래 살기'이다. 장수와 관련된 연구들에서 공통된 사항 은 양심적, 외향성, 개방성, 적극성 등이다(Bahn 2018).

\section{치료 종결 후 치료자-피분석자 관계}

전통 분석 이론에서는 치료 종결 후 분석가 상실에 따른 환자의 애도 반응을 돕기 위해 환자와 분석가의 분리를 주장 하였으나, 완전한 분리 혹은 환자-분석가 접촉이 애도 반응 처리에 영향을 미친다는 근거는 확실치 않다(Craige 2002). 일부 분석가들은 소수 사례를 통해 분석 종료 후 만남이 환 자에게 도움이 되었다고 보고하였다(Schachter 등 1997). 분 석가는 분석 종결 단계에서 종결의 다른 개념을 환자에게 소개해 줄 수 있다(Schachter 등 2014). 즉, 종결 후 만남 가능 
성과 그 장점에 대해 설명해 준다. 첫째, 분석가가 환자를 돌 봐 주었음을 재경험한다. 특히 외로움을 많이 호소한 노인 환 자의 경우 비공식적, 자발적으로 이루어지는 것이 좋다. 둘 째, 분석가 함입을 강화할 수 있다. 셋째, 분석가에 대한 해결 되지 않은 이상화를 다룰 기회가 된다. 넷째, 종결 후 일어나 는 환자의 변화에 대해 조언할 수 있으며, 분석치료에 대한 인 식을 향상시킬 수 있는 기회가 된다. 분석 종결 후 만남은 환 자는 물론 분석가에게도 도움이 되므로 치료비를 부과하지 않는 것이 합리적이다. 단, 종결 후 만남에서도 분석가는 전문 가 역할을 유지해야 한다. Kantrowiz(2014)는 정신치료자나 분석가가 치료 종결 후 피분석자를 만나는 것이 도움이 될 것 이며, 치료적 이득에 해가 될 것은 없다고 결론지었다. 특히 노인 환자가 겪는 상실과 외로움에 대해서 정신분석적 치료 가 도움이 될 수 있으며, 치료 종결 후 환자-분석가 만남을 통 해 환자가 새로운 인간관계를 맺을 수 있도록 돕고, 취미 활 동을 해 나가도록 지지해 줄 수 있다(Schachter 등 2014).

\section{결 론}

정신분석에서 성인기 연구가 한동안 침체되었던 이유는 성인은 완성체이므로 더 이상의 분석이 필요하지 않다는 판 단 때문이었다. 그러나 신경생물학적으로도 성인기의 중추 신경계는 계속 변화하고 있으며, 성인기에 접어들면 결혼, 출산, 취업 등 이전과 전혀 다른 발달 과제를 접하고 해결해 가야 한다. 의학의 발전으로 평균 수명이 과거에 비해 크게 연장되면서 한 세기 전에는 거의 고려할 필요도 없었던 노년 기의 삶에 대해 고민하게 되었다. Erikson이 사회문화적 발 달 과제 이론을 제시한 이후 여러 학자들이 노년기를 포함한 성인기 발달에 대한 연구결과를 보고하였다. 중년기에 접어 들면 이전과 가장 큰 차이를 보이는 내용은 죽음과 상실 주 제이다. 고령기 환자의 경우 치료자가 경험하지 못한, 그리고 인지하기 어려운 새로운 형태의 갈등을 해결하고 싶어할 수 도 있다. 각 연령대별로 적절한 정신치료 작업을 수행하기 위 해 치료자는 충분한 지식과 대비책을 숙달해야 할 것이다.

\section{Acknowledgments}

The theme of this article was presented at the intensive psychotherapy workshop for the psychiatrists of the Korean Association of Psychoanalysis on 5th October, 2019, Seoul, Republic of Korea. The author thanks YoonSik Suh to help prepare the draft volunteering from the end of June to the middle of July, 2019.

\section{Conflicts of Interest}

The author has no potential conflicts of interest to disclose.

\section{ORCID iD}

Geon Ho Bahn: https://orcid.org/0000-0002-3550-0422

\section{REFERENCES}

Abraham K. The applicability of psychoanalytic treatment to patients at an advanced age (1919). In: Abraham K. Selected papers of Karl Abraham. London: Hogarth press;1927. p.312-317.

Allen JG, Fonagy P, Bateman AW. Mentalizing in clinical practice. Washington, DC: American Psychiatric Association Publishing;2008.

Bahn GH. From attachment theory to mentalization: historical background and clinical implications. Psychoanalysis 2013;24:9-20.

Bahn GH, Ryu JE, Lee YJ, Han J, Lee A, Hong M. When is the endpoint of the adolescence? Psychoanalysis 2015;26:3-17.

Bahn GH. What psychotherapy do centenarians need? Psychoanalysis 2018;29:27-32

Blos P. The second individuation process of adolescence. Psychoanal Study Child 1967;22:162-186.

Brandão D, Ribeiro O, Jopp D. Would I want to reach age 100? Perspectives of centenarians' family members on reaching exceptional longevity. J Fam Issues 2019;40:1086-1101.

Colarusso CA, Nemiroff RA. Adult development: a new dimension in psychodynamic theory and practice. New York, NY: Plenum Press; 1981.

Colarusso CA. Child and adult development: a psychoanalytic introduction for clinicians. New York, NY: Plenum Press;1992.

Colarusso CA. Traversing young adulthood: the male journey from 20 to 40. Psychoanal Inq 1995;15:75-91.

Colarusso CA. Separation-individuation phenomena in adulthood: general concepts and the fifth individuation. J Am Psychoanal Assoc 2000;48:1467-1489.

Colarusso CA. The evolution of paternal identity in late adulthood. J Am Psychoanal Assoc 2005;53:51-81.

Craige H. Mourning analysis: the post-termination phase. J Am Psychoanal Assoc 2002;50:507-550.

Crimmins EM. Lifespan and healthspan: past, present, and promise. Gerontologist 2015;55:901-911.

Diamond MJ, Christian C. The second century of psychoanalysis: evolving perspectives on therapeutic action. London: Karnac Books;2011.

Erikson EH. Childhood and society. New York, NY: W. W. Norton \& Company; 1963.

Freud S. On psychotherapy. SE 7. London: Hogarth Press;1905. p.255268.

Freud S. The dynamics of transference. SE 12. London: Hogarth Press; 1912. p.99.

Greenson RR. Crisis in adult life: prevention and survival (1974). In: Nemiroff RA, Sugarman A, Robbins A. On loving, hating, and living well: the public psychoanalytic lectures of Ralph R. Greenson. Madison, CT: International Universities Press;1992. p.297-312.

Hoffman E. (Trans. Kim PJ, Park WJ). The drive for self: Alfred Adler and the founding of individual psychology. Seoul: Geulhangari;2019.

Hollis J. The middle passage: from misery to meaning in midlife. Toronto: Inner City Books;1993. p.7, 23-27, 94, 116.

Jacobs JM, Cohen A, Ein-Mor E, Stessman J. Gender differences in survival in old age. Rejuvenation Res 2014;17:499-506.

Jaques E. Death and the mid-life crisis. Int J Psychoanal 1965;46:502514.

Jeong HC, Kim SU, Lee WC, Kim MT, Lee WK, Kim HY, et al. Sexual behavior of the elderly in urban areas. World J Mens Health 2012; 30:166-171.

Kandel ER. Interview with Eric R. Kandel: from memory, free will, and the problem with Freud to fortunate decisions. J Vis Exp 2008;(15). pii: 762 .

Kantrowitz JL. Myths of termination: what patients can teach psychoanalysts about endings. New York, NY: Routledge;2014.

Kestenberg JS. Regression and reintegration in pregnancy. J Am Psychoanal Assoc 1976;24:213-250.

Lansky MR. The borderline father: reconstructions of young adulthood. 
Psychoanal Inq 1987;7:77-98.

Levinson DJ, Darrow CN, Klein EB, Levinson MH, McKee B. The seasons of a man's life. New York, NY: Ballantine Books;1978. p.80.

Lindau ST, Schumm LP, Laumann EO, Levinson W, O'Muircheartaigh CA, Waite LJ. A study of sexuality and health among older adults in the United States. N Engl J Med 2007;357:762-774.

Mahler MS. On the first three subphases of the separation-individuation process. Int J Psychoanal 1972;53:333-338.

Martin-Joy JS, Malone JC, Cui XJ, Johansen PØ, Hill KP, Rahman MO, et al. Development of adaptive coping from mid to late life: a 70 -year longitudinal study of defense maturity and its psychosocial correlates. J Nerv Ment Dis 2017;205:685-691.

Moon DS, Bahn GH. The concept of synchronization in the process of separation-individuation between a parent and an adolescent. Psychoanalysis 2016;27:35-41.

Offer D, Offer JB. From teenage to young manhood: a psychological study. New York, NY: Basic Books; 1975.

Parens H. Parenthood as a developmental phase. J Am Psychoanal Assoc 1975;23:154-165.

Park K, Chung HS. Sexual health and sexual activity in the elderly. J Korean Med Assoc 2019;62:301-307.

Schachter J, Martin GC, Gundle MJ, O'Neil MK. Clinical experience with psychoanalytic post-termination meetings. Int J Psychoanal 1997; 78:1183-1198.
Schachter J, Kächele H, Schachter JS. Psychotherapeutic/psychoanalytic treatment of the elderly. Psychodyn Psychiatry 2014;42:51-63.

Settlage CF, Galenson E. Psychology of women: late adolescence and early adulthood. J Am Psychoanal Assoc 1976;24:631-645.

Spitz RA. The first year of life: a psychoanalytic study of normal and deviant development of object relations. New York, NY: International Universities Press; 1965.

Statistics Korea [Internet]. Daejeon: Women's life in statistics 2018; c2018 [cited 2019 Aug 1]. Available from: http://kostat.go.kr/portal/ eng/pressReleases $/ 13 / 1 /$ index.board?bmode $=$ read\&bSeq $=\& a S e q=375$ 795\&page $\mathrm{No}=1$ \&rowNum $=10$ \&navCount $=10 \&$ currPg $=\&$ searchInfo $=\&$ sTarget=title\&sTxt $=$.

Vaillant GE. Adaptation to life. Boston, MA: Little Brown and Co.;1977.

Vaillant GE, Vaillant CO. Natural history of male psychological health, XII: a 45-year study of predictors of successful aging at age 65. Am J Psychiatry 1990;147:31-37.

Vaillant GE. Positive mental health: is there a cross-cultural definition? World Psychiatry 2012;11:93-99.

Witherow MP, Chandraiah S, Seals SR, Sarver DE, Parisi KE, Bugan A. Relational intimacy mediates sexual outcomes associated with impaired sexual function: examination in a clinical sample. J Sex Med 2017; $14: 843-851$

Yoon $\mathrm{H}$. Necessity and methods of sexual education in the elderly population. J Korean Med Assoc 2019;62:320-324. 